\title{
Firm Size, Financial Distress, Audit Quality, and Earnings Management of Banking Companies
}

\author{
Angela Kurniawati $^{1 *}$, Rosinta Ria Panggabean ${ }^{1}$ \\ ${ }^{1}$ Department of Accounting, Faculty of Economics \& Communication Bina Nusantara University Jakarta, Indonesia \\ "Corresponding author. Email: angelakurniawati@gmail.com
}

\begin{abstract}
The era of globalization has stimulated the spirit of competition of companies in an ever-intensifying business race of various sectors. In an attempt to sustain the life of the company, earnings figures are kept positive to attract investors and to elevate the company's social status. This study aims to examine whether firm size, financial distress, and audit quality are influenced by earnings management. This research is a quantitative study from secondary data. A sample of 12 banking companies listed on the Indonesia Stock Exchange in 2014-2018 was used in this research. This research also employed descriptive analysis and panel data regression analysis. Results showed that firm size had a significant negative effect on earnings management; financial distress had a significant positive effect on earnings management; whereas audit quality had no significant effect on earnings management. A multitude of issues arising in banking companies involve earnings management behaviour. It is suggested that investors and the public perform a deeper analysis of the companies in which to invest. Companies are also advised against earning management practices harmful to financial statement users.
\end{abstract}

Keywords: firm size, financial distress, audit quality, earnings management, banking companies

\section{INTRODUCTION}

The era of globalization has led to restrictions on trade between free and open countries. This triggers the competitiveness and competitive spirit of each company in order to excel in fierce business competition. There are many obstacles in the company's efforts to win the competition, especially in terms of corporate funding. Limited funds can be overcome by the addition of funds by the founders of the company and third parties in the business, of course on the condition that the company's condition can be accounted for business continuity. For this reason, the company will strive for and be valued by both investors and the public. Financial statements are an indicator of a company's success and are reflected in the profits generated. Actions taken by managers with the aim of influencing earnings results by raising or lowering profits are a form of earnings management [1].

Earnings management occurs when managers use a creative mindset in preparing financial statements by intervening in transactions that occur, thus giving another impression of the information presented and affecting the actions of stakeholders who depend on financial statements [2]. Acts of earnings management can occur in both large and small companies; in this case earnings management can occur in all companies in general. Reference [3] states that company size has a negative effect on earnings management, assuming the mass attention is focused on large companies, then companies tend to display reports that can be trusted so that it reduces earnings management actions. Whereas [4], also supported by [5], found that large companies face more pressure from investors and financial analysts to show positive results from company profits. Many companies have experienced financial distress in recent years. This can be seen by the number of companies that have been delisted by the IDX. When a company experiences difficulties due to market conditions and internal problems, various strategies are implemented to cover the company's deteriorating conditions, from sorting and establishing accounting methods that are considered capable of maximizing profits [6] to manipulating financial results as a tool to reflect that the company's economic conditions and situation are well [7]. This makes financial distress as one of the factors considered to influence earnings management behavior. The results of research [8] and [9] prove that financial distress affects earnings management, where companies that do not experience financial distress are involved in high earnings management. Meanwhile, Audit quality is the auditor's probability of providing an unqualified audit opinion for financial statements that are proven to have material errors [10]. In everyday reality, audit quality does not guarantee that financial statements are proven to be free from material misstatements.

This research is expected to help those with an interest as a contribution of thought and innovation to help improve the quality of educational institutions. It may also be beneficial for the internal parties of a company as a platform for decision making in implementing company management policies; as well as parties outside of a company to consider analyzing the condition of a company before investing and the possibilities that might occur. 


\section{METHOD}

The type of data used in this study was secondary data, while the data source were annual financial statement data from banking companies listed on the Indonesia Stock Exchange (IDX). Financial statement data was obtained from the website www.idx.co.id for companies taken from the fact book data on the IDX website. Panel data was used in this study.

\subsection{Research Object}

The object of research were banking companies listed on the Indonesia Stock Exchange (BEI) for five consecutive years from 2014 to 2018.

\subsection{Sample Collection Method}

The researchers used the purposive sampling method in the process of collecting the data samples. The documentation method was used to obtain data needed in research derived from financial statements of banking companies from the Indonesia Stock Exchange (IDX). This study used the industrial population of banking companies listed on the IDX.

\subsection{Data Analysis Method}

The data analysis method used was the descriptive data analysis technique. This technique utilizes multiple linear regression analysis techniques using Eviews version 9.0. Tests conducted in this study consisted of descriptive statistical tests, classic assumption tests and hypothesis tests [19].

\subsection{Operationalization Variables}

In this study, operational variables are the determination of how to measure each variable so that it is possible for researchers to replicate measurements in the same way or develop better ways of measurement. The variables that are operationalized in this study are as follows:

\subsection{Dependent Variable}

The dependent variable used in this study is earnings management. Calculation of earnings management (discretionary accruals) uses the Modified Jones Model.

\subsection{Independent Variables}

The following is the description of each operationalization of the independent variables in this study: a. Company Size

The formulas used to calculate company size in this study using natural logarithm of total assets.

b. Financial Distress

In this study, financial distress is measured based on the research model conducted by [12]. Financial distress is measured using the Altman Z-Score Model

c. Audit Quality

In this study, audit quality is measured through the size of the Public Accounting Firm (KAP). The size is measured on a nominal scale through a dummy variable. Number 1 is used to represent companies audited by Big $4 \mathrm{KAP}$ and number 0 is used to represent companies that are audited by Non-Big 4 KAP.

\section{RESULTS AND DISCUSSION}

The companies that are the objects of this research are banking sector companies listed on the Indonesia Stock Exchange in the period 2014 to 2018. Based on the predetermined criteria, the results of sample selection are presented in Table 1.

Table 1 Sample Selection

\begin{tabular}{|lll|}
\hline 1 Number of banking companies listed on & 45 \\
the Indonesia Stock Exchange over five & \\
periods from 2014-2018 & \\
2 & $\begin{array}{l}\text { Companies that did not publish } \\
\text { consecutive financial statements from }\end{array}$ \\
& $\begin{array}{l}\text { 2014-2018 } \\
\text { Companies that have negative net profit }\end{array}$ & $(6)$ \\
& figures \\
4 & $\begin{array}{l}\text { Companies that do not have accounts } \\
\text { receivable numbers }\end{array}$ & $(5)$ \\
\hline Total sample companies & 22 \\
Total research data for 5 years & 110 \\
\hline
\end{tabular}

\subsection{Testing the Panel Data Regression Model Selection}

From the Chow Test results, it is found that the result of probability $\mathrm{F}$ is 0.0000 ; this is smaller than 0.05 , so the best model is the fixed effect. Based on the Hausman Test results, the probability number is known to be 0.1516 ; this is above 0.05 , thus the best model is the random effect model. Based on the Lagrange test, the Breuch Pagan Cross Section value is 0.0000 , which is smaller than 0.05 , so it is better to use the random effect regression model. From the whole test for panel data estimation techniques, the best panel data regression model to use is the random effect model.

The following are the results of the descriptive statistical analysis processed using the eviews software 
Table 2 Descriptive statistics

\begin{tabular}{|llrrrc|}
\hline & n & Minimum & Maximum & Mean & Std Dev \\
\hline ML & 110 & -1.125272 & 0.158989 & -0.063478 & 0.208594 \\
\hline SIZE & 110 & 29.20557 & 34.79875 & 32.07537 & 1.507113 \\
\hline FD & 110 & 3.593227 & 11.35293 & 6.377011 & 1.185815 \\
\hline KA & 110 & 0.00000 & 1.000000 & 0.809091 & 0.394816 \\
\hline
\end{tabular}

\subsection{Classic Assumption Test}

The following normality test results consist of the results of the initial normality test with a sample of 110 data and the results of the normality test after the elimination of outliers amounting to 60 data. Based on the results of the initial normality test, it is found that the value of the fallow jar (JB) is 105.0642 , and the probability value is 0.0000 . This value is smaller than the requirement to pass the normality test, ie the probability of above 0.05 . This concludes that the data are distributed abnormally. The normality test is basically not a BLUE (Best Linear Unbias Estimator) requirement. However, because the use of the $\mathrm{F}$ test and $t$ test requires that the error factor follows the normal distribution, the normality test is still carried out in this study [14].

The test is carried out once again after eliminating the outlier sample. Based on the normality test after eliminating the outlier, the probability value is found to be 0.384017 . This value is greater than 0.05 , meaning that the data has been normally distributed. The following are results from the multicollinearity test before outlier and after outlier elimination.

Table 3 Multicollinearity test

\begin{tabular}{|cccc|}
\hline \multicolumn{2}{|c|}{ Before outlier elimination } & \multicolumn{2}{c|}{ After outlier elimination } \\
\hline Variable & Centered VIF & Variable & Centered VIF \\
\hline SIZE & 1.232366 & SIZE & 2.914188 \\
\hline FD & 1.308548 & FD & 2.176742 \\
\hline KA & 1.269327 & KA & 1.921206 \\
\hline
\end{tabular}

From the results of Table 3 , it can be seen that the centered VIF in each of the SIZE, FD, and KA variables show VIF values below 10 . These three results show a value below 10 , so it can be concluded that the study is free from multicollinearity, hence a multiple linear regression test can be performed on the research data.

This study utilizes the White Heteroskedasticity Test. The results of the heteroscedasticity test before eliminating outliers show that the Chi Square probability number is 0.0001 and smaller than 0.05 , so the results of this research experience heteroscedasticity. References [14] state that if there is heteroscedasticity in the model, improvements are needed to avoid misleading conclusions. The consequence of heteroscedasticity can result in the OLS predictors obtained to still meet unbiased requirements, but the variants obtained become inefficient, meaning that the variants tend to enlarge so that they are no longer small variants. Thus the model first needs to be improved so that the effect of heteroscedasticity is lost [15]. After the process of eliminating outliers, the overall sample of companies numbered to 12 companies, with a total of 60 companies.
Heteroscedasticity test results after eliminating outliers show that the Chi Square probability value is 0.0629 and greater than 0.05, making it is free from heteroscedasticity. The calculated F probability value (Prob Chi Square) after the elimination of outliers was 0.4518 ; this value is greater than 0.05 , so based on the autocorrelation test performed it can be concluded that there was no autocorrelation in this study.

\subsection{Hypothesis Test}

Based on the results of the coefficient of determination test, the Adjusted R-Squared value was found to be 0.458405 . From these results, it can be concluded that the independent variables in this study comprising of company size, financial distress and audit quality can explain the dependent variable in this study, namely earnings management, by $45.84 \%$. The remaining $54.16 \%$ is influenced by other variables not included in this study. From the results of the F test, the Prob (F-statistic) was found to be 0.000048 . From these results, it can be interpreted that together these three independent variables significantly influence earnings management.

The results of the t test can be elaborated as follows:

1. The SIZE variable (Company Size) has a probability value of 0.0033 . This value is lower than the standard significance level of 0.05 , thus it can be said that the company size variable influences earnings management.

2. The variable FD (Financial Distress) has a probability value of 0.0000 ; this number is lower than the standard significance level of 0.05 , so it can be stated that the financial distress variable influences earnings management.

3. The KA variable (Audit Quality) has a probability value of 0.3319 ; this number is greater than the standard significance level of 0.05 , so it can be concluded that the audit quality variable has no effect on earnings management.

The equation of the regression model in which the $\mathrm{Y}$ variable in this study is ML (Earnings Management), and the $\mathrm{X}$ variables are SIZE (Company Size), FD (Financial Distress) and KA (Audit Quality), respectively, are as follows:

$\mathrm{ML}=2.495136-0.093879 \mathrm{SIZE}+0.089512 \mathrm{FD}-0.027657$

$\mathrm{KA}+\varepsilon$ 


\subsection{Effect of Company Size on Earnings Management}

Hypothesis testing has shown the results of the effect of company size on earnings management, which shows that the company size variable had a negative and significant effect on earnings management on banking companies listed on the Indonesia Stock Exchange in the period 20142018. . This research proves that the larger the size of the company, the more attention the public has on the company, so the company avoids earnings management behavior to safeguard the reputation and trust of external parties. In addition, the larger the size of the company, the motivation in managing earnings decreases, because large companies are more stable in their economic conditions. This supports the research conducted by [3]. From the overall research, it is noted that company size affects earnings management in the company negatively and significantly throughout the entire study period.

\subsection{Effects of Financial Distress on Earnings Management}

Hypothesis test results indicate that the financial distress variable had a positive and significant effect on earnings management in banking companies listed on the Indonesia Stock Exchange in the 2014-2018 period. This states that companies that are experiencing financial difficulties will perform earnings management. The higher the level of financial difficulties, earnings management behavior will also increase. Moreover, this study is also in line with [16] who found a positive relationship where the healthier the company, the greater the real income management performed through the management of production costs and discretionary expenses. On the contrary, the lower the financial health of a company, the greater the amount of accrual earnings management done through the management of the discretionary accrual component.

\subsection{Effect of Audit Quality on Earnings Management}

Based on the results of hypothesis testing, the results show that audit quality had no effect and is significant on earnings management in banking companies listed on the Indonesia Stock Exchange in the 2014-2018 period. In agency theory, the agency provides an explanation for why the higher quality of Big 4 auditors is demanded. Given that one way to reduce agency costs is to increase monitoring in situations where there is a high conflict between managers (agents) and owners (principals). Based on the results of research that rejects the hypothesis of the influence of company size on earnings management, these results support the research of [17] and [18] which states that audit firm size does not guarantee it to have a good audit quality. This is possible how earnings management practices occur, but it ignores the existence of the Big 4, and also Big 4 auditors do not reduce earnings management actions, but rather make efforts to present financial statements that are more reliable through audit quality from Big $4 \mathrm{KAP}$.

\section{CONCLUSION}

This study aims to determine whether the independent variables of company size, financial distress and audit quality affect the dependent variable of earnings management. Based on the results of the hypothesis carried out by multiple linear regression, this study obtained the following conclusions: Company size has a negative and significant effect on earnings management practices. The results of this study support research [3] regarding the negative relationship between company size and earnings management practices. Financial distress has a positive and significant effect on earnings management practices. The results of this study support the research of [8], [16], and [12]. Meanwhile, Audit quality has no influence and is not significant to earnings management practices. This supports the research of [17] as well as [18]

\section{ACKNOWLEDGMENT}

The authors would like to thank Bina Nusantara University for the opportunity to conduct research so that this article can be realized.

\section{REFERENCES}

[1] R. A. Supriyono. (2018). Akuntansi Keperilakuan. Yogyakarta: Gadjah Mada University Press .

[2] Hery. (2015). Analisis Kinerja Manajemen. Jakarta: Gramedia Widiasarana.

[3] P. Prasetya and Gayatri. (2016, January). Pengaruh ukuran perusahaan terhadap manajemen laba dengan pengungkapan corporate social responsibility sebagai variabel intervening. E-Jurnal Akuntansi, Vol. 14, No. 1, pp. 511-538. Available:

https://ojs.unud.ac.id/index.php/Akuntansi/article/view/ 17482

[4] Amertha, I. S. Prasavita, I. K. Ulupui, and I. A. Putri. (2014). Analysis of firm size, leverage, corporate governance on earning management practices (Indonesia evicence). Journal Of Economics, Business, and Accountancy Ventura Vol. 17 No. 2. Available: https://journal.perbanas.ac.id/index.php/jebav/article/vi ew/308

[5] Turegun. (2016, November). Effects of Borrowing Cost, Firm Size, and Characteristics of Board of Directors on Earnings Management Types: A Study at Borsa Istanbul. Asia-Pacific Journal of Accounting and Economics. Vol. 25, Issue 1-2. Available: 
https://www.tandfonline.com/doi/abs/10.1080/1608162 5.2016 .1246192

[6] N. P. L. A. Utari and M. M. R. Sari (2016, September). Pengaruh asimetri informasi, leverage, kepemilikan manajerial dan kepemilikan institusional pada manajemen laba. E-Jurnal Akuntansi, Vol. 16, No. 3, pp. 1687-1715. Available:

https://ojs.unud.ac.id/index.php/Akuntansi/article/view/ 16390

[7] A. P. Lopes. (2018). Audit quality and earnings management: Evidence from Portugal. Athens Journal of Business \& Economics, Vol. 4, No. 2, pp. 179-192. Available:

https://www.athensjournals.gr/business/2018-4-2-4Lopes.pdf

[8] K. Agrawal and C. Chatterjee. (2015, September). Earnings management and financial distress : Evidence from India. Global Business Review, Vol. 16, No. 5S, pp. 140S-154S. Available:

https://journals.sagepub.com/toc/gbra/16/5_suppl

[9] K. M. Nalarreason, T. Sutrisno, and E. Mardiati. (2019). Impact of leverage and firm size on earnings management in Indonesia. International Journal of Multicultural and Multireligious Understanding Vol. 6, No. 1, pp. 19-24. Available:

https://ijmmu.com/index.php/ijmmu/article/view/473/3 48

[10] Junaidi and Nurdiono. (2016). Kualitas Audit: Perspektif Opini Going Concern. Yogyakarta: Andi.

[11]P. M. Dechow, R. G. Sloan, and A. P. Sweeney. (1995,April). Detecting earnings management. The Accounting Review Vol. 70, No. 02, pp. 193-225. Available: https://www.jstor.org/stable/248303

[12] A. T. Gupta and I. W. Suartana. (2018, May). Pengaruh financial distress dan kualitas corporate governance pada manajemen laba. E-Jurnal Akuntansi. Vol. 23, No.2, pp. 1495-1520. Available:

https://ojs.unud.ac.id/index.php/Akuntansi/article/view/ 37991

[13] F. A. Gul and S. Fung. (2019). Hong Kong Auditing: Economic Theory and Practice. Hong Kong: City University of Hong Kong Press.

[14] A. T. Basuki. (2018). Pengantar Ekonometrika (Dilengkapi Penggunaan Eviews). Yogyakarta: Danisa Media.

[15] D. Gujarati. (2003). Ekonometri Dasar. Jakarta: Erlangga.

[16] D. R. Muljono and S. S. Kim. (2018, May). Impacts of financial distress on real and accrual earnings management. Jurnal Akuntansi, Vol. 22, No. 2, pp. 222-238. Available:

http://ecojoin.org/index.php/EJA/article/view/349/325

[17] A. C. Turnip, D. Pratomo, and S. P. Yudowati. (2016, December). Pengaruh kualitas audit dan kepemilikan manajerial terhadap manajemen laba. EProceeding of Management Vol. 3, No. 3, pp. 31763182. Available:

https://ibraryeproceeding.telkomuniversity.ac.id/index. php/management/article/view/3455/3278

[18] I. Christiani and Y. W. Nugrahanti. (2014). Pengaruh kualitas audit terhadap manajemen laba. Jurnal Akuntansi dan Keuangan, Vol. 16, No.1, pp. 5262. Available: http://jurnalakuntansi.petra.ac.id/index.php/aku/article/v iew/19157.

[17] Nuryanto and Z. B. Pambuko, EViews untuk Analisis Ekonometrika Dasar - Aplikasi dan Interprestasi, 1st ed. Magelang: Unimma Press, 2018. 